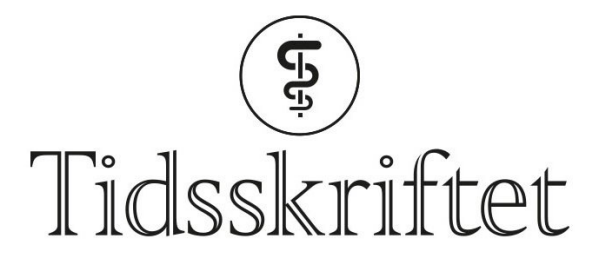

DEN NORSKE LEGEFORENING

\title{
Legen og lyrikken
}

INTERVJU

MARIT TVEITO

E-post: marit.tveito@aldringoghelse.no

Hver dag sender Arild Vedvik ut tre dikt til de som deltar i Poesiringen. Fastlegen synes livet er blitt rikere av interessen som har gitt ham nesten tretti tusen følgere på Facebook og mange nye venner. Han deler kunst inn i det som berører og det som ikke berører.

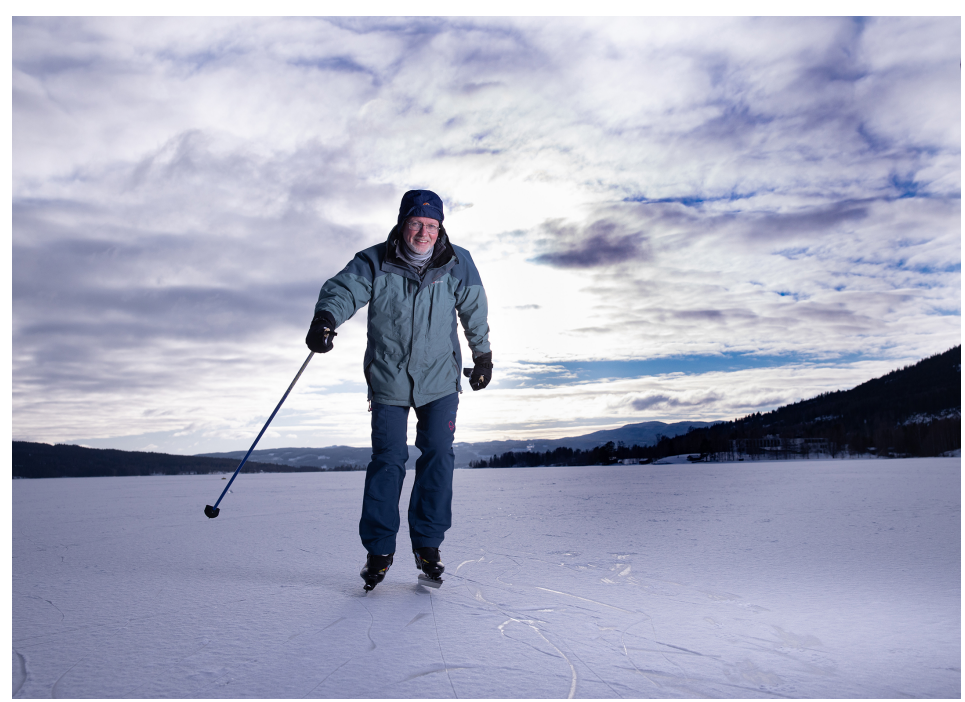

Foto: Frode Mikal Nilssen / Hurdal Foto

Hjemmet til familien Vedvik ligger vakkert til med utsikt over Hurdalssjøen, en stor hage og turmuligheter rett utenfor døren.

- Hurdal ble kalt «Østlandets perle» i geografibøker, forteller Vedvik på vei opp trappen. Veggene i eneboligen er dekket av bøker, bilder og tekstilkunst.

- Er det derfor det er flere skilt til steder som heter noe med «recovery» på veien?

- Vi mennesker er designet for å være i naturen. Hurdal kan by på varierte naturopplevelser med både fjell og sjø, og fortsatt skikkelig vinter. «Recovery» er navnet på det psykiatriske sykehuset her, som prøver å få til medisinfri behandling.

Han henter varme kanelboller og viser veien til vinterhagen.

- Hjemmelagde?

- Ja, men ikke hos oss.

Han gir æren til en lokal kvinne med gode bakeferdigheter, før han setter seg til rette i stolen. 
- Hva skal du snakke med meg om da?

Han snakker med en mild og avslepen bergensdialekt.

- Nei, det må vel bli de sentrallyriske temaene?

\section{Poesiringen}

I en årrekke har Vedvik formidlet poesi til alle interesserte via e-post og Facebook.

- Hvordan begynte det?

- Jeg jobbet ved Hurdal Rehabiliteringssenter. Pasientrommene var temmelig spartansk innredet, og jeg tenkte at vi kunne henge opp dikt og bilder på hvert rom. Etter å ha spurt noen venner om de hadde forslag til dikt som kunne egne seg, fikk jeg overraskende mange fine dikt tilbake. I takknemlighet sendte jeg ut det de hadde sendt inn, og da sendte de mer. Etter kort tid ble det daglige utsendelser. Det begynte med en tanke, så ble det personlig berikende. Etterhvert ble det nesten et slags kall, hvis det går an å bruke det uttrykket? Jeg opplever så mye takknemlighet for det lille bidraget Poesiringen er, at jeg ikke klarer å slutte.

\section{Arild Vedvik}

Cand.med. 1983, Universitetet i Oslo

Spesialist i allmennmedisin 1992

Kommunelege i Hurdal fra 1987

Fastlege fra 2001

Har drevet Poesiringen siden 2003. Hvis du vil bli med, kan du skrive til poesiringen@gmail.com

- Hvor ofte sender du ut dikt?

- Jeg sender ut tre dikt via e-post hver dag, såfremt jeg har tilgang til internett. I tillegg legger jeg de ut på Facebook, vanligvis ledsaget av bilder. På Facebook er det 29 ooo følgere, mens et par tusen får diktene per e-post.

- Vet du hvem du sender til?

- Blant de som får e-post kjenner jeg en god del. På Facebook er det flest ukjente. Derfra deles diktene videre, og ifølge statistikken når de ut til mellom 100 ooo og 250 ooo personer hver måned.

Det begynte med en tanke, så ble det personlig berikende

- Har du blitt kjent med mange på grunn av Poesiringen?

- Ja. Poesi, som all kunst, handler om livet. Uansett hvilke følelser man har, er det en poet som har beskrevet det. Det er alltid noen som føler seg trøstet, hjulpet, gledet, opplyst eller berørt. Jeg får tilbakemeldinger både på Facebook og privat. Da blir man kjent med folk. Den gaven er verdt all jobben.

- Hender det at du treffer de som svarer?

- Det hender at vi får besøk av både kjente og ukjente personer. Noen har blitt familievenner. Det kommer også invitasjoner i ulike sammenhenger. Folk som synger er ofte opptatt av tekst og tekstformidling. Lyrikk betyr opprinnelig «det som kan synges til en lyre», og det er mange musikere med i Poesiringen. Rim og rytme passer inn en melodi, og det gjør at den huskes. Selv personer med demens husker jo sanger de har lært før.

- Poesiringen har også nådd ut i verden?

- Facebook leverer mye statistikk, og Poesiringen har følgere i 45 land, av folk med 38 
forskjellige morsmål. Jeg vet ikke om de bruker Google Translate, om de er norske hjelpearbeidere eller tospråklige. Jeg ser bare antallet og hvor de følger fra.

- Er det mange pasienter som følger ringen?

- Det er det.

\section{Poesien og pasientene}

- Bruker du poesi i jobben?

- Det spørsmålet har jeg fått mange ganger. For mange år siden inviterte professor i allmennmedisin Edvin Schei meg til å skrive et kapittel i en bok som heter Forstår du, doktor? Han spurte om jeg ville skrive om legelivet og poesi. Da prøvde jeg ut poesi i konsultasjoner av og til, men jeg er ikke noen poesidoktor eller alternativ lege: «Ta dette diktet og se om det hjelper?».

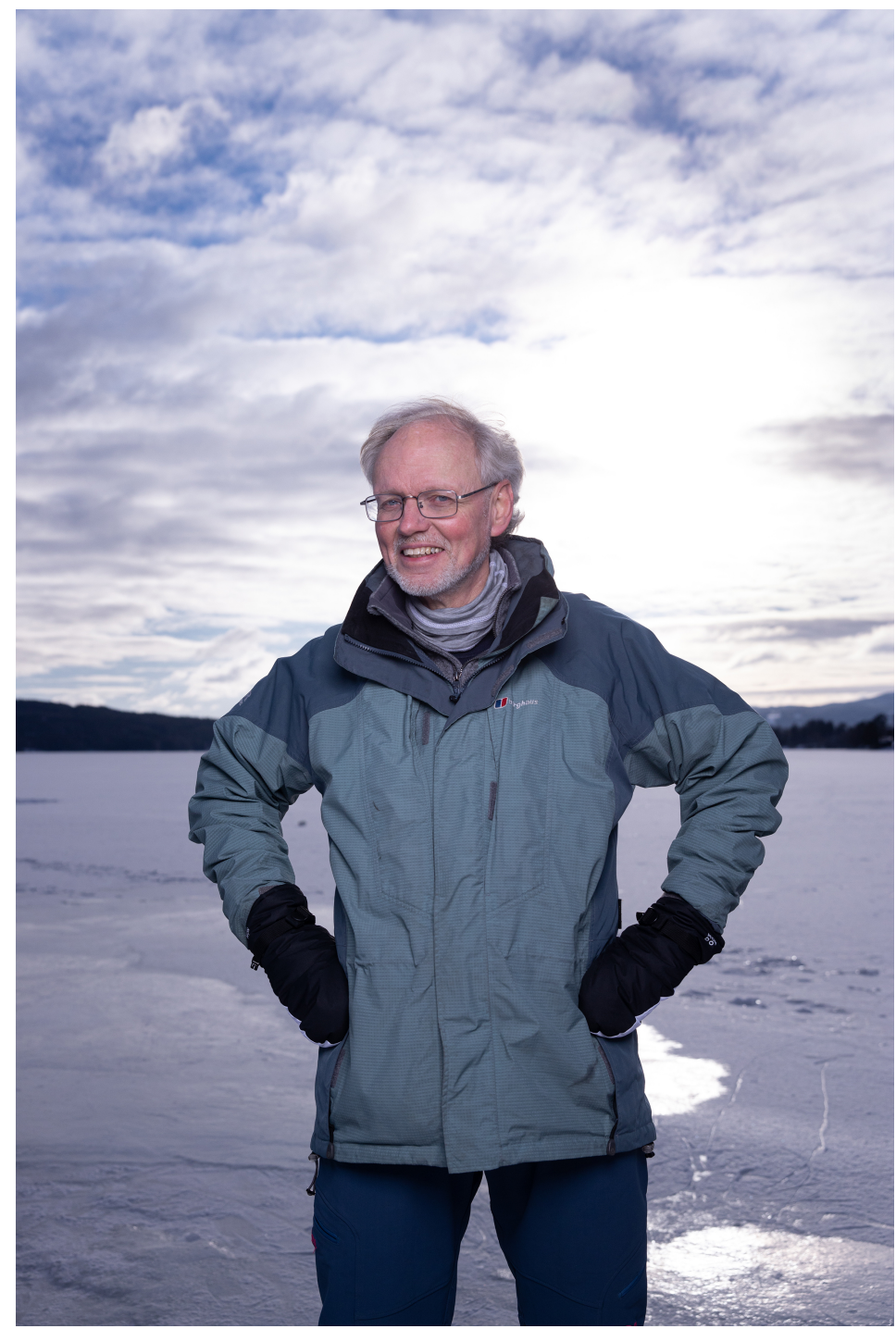

Foto: Frode Mikal Nilssen / Hurdal Foto

Han humrer godt.

- Av og til merker du at pasienter har en kanal for dette. Det hender en gang i blant at pasienter gir meg et dikt. Noen pasienter som sliter skriver selv, og gir meg det for å lese. Særlig opplever jeg at pasienter med psykiske lidelser skriver dikt og andre tekster. Jeg tror det kan være terapeutisk å sortere og sette ord på tanker og følelser. Skrive det ned, og legge det bort. Det hender at jeg finner frem et dikt som har noe med pasientens situasjon å gjøre. Det har også hendt at jeg har gitt et dikt til en pasient på vei ut døra. Ved neste konsultasjon kommer kanskje en traumatisk historie til overflaten. Forskjellige verktøy virker på forskjellige folk. 
- Hvordan kan leger og andre i helsevesenet bruke poesi i møtet med mennesker?

- Det å være syk kan fort bli en eksistensiell situasjon, enten det er en alvorlig eller kronisk sykdom som begrenser din måte å leve livet på. Poesi handler om det eksistensielle på et eller annet nivå. Om livet. Og hvis pasienter kan oppleve gjenkjennelse, trøst eller håp hvorfor ikke?

- Det er gratis, uten bivirkninger og jeg har sett at det kan virke. I USA kalles det poetry therapy, og undervises ved 200 medisinske fakulteter. Det kan handle om å lære pasienter å skrive, for slik å sette ord på ting som er for vondt til å si. Det kan være å lese en tekst i en gruppe, og så kan pasienten relatere til teksten. Og så er det den finurlige tingen: At det er lettere å snakke om det som pasienten har skrevet, enn opplevelsen direkte, selv om det handler om det samme. Dette er en parallell til kunstterapi der pasienten tegner, og etterpå snakker om tegningen. Jeg tror Picasso hadde rett da han sa at «kunsten børster hverdagens støv av livet». Jeg synes det er vakkert og sant. Noen ganger må vi rykkes ut av vanetenkningen. Et bilde, et dikt eller en film kan gjøre det.

- En venn sier at du deler din kunst i to grupper - det som berører og det som ikke berører.

- Dikt er ulike, folk er ulike, og livssituasjonen er varierende. Dikt kan treffe noen personer, mens for andre gir de ingen mening. Jeg tror de fleste som leser ønsker å finne noe som treffer, berører, eller kanskje hjelper å se ting på en ny måte. Kanskje vil de bare fornemme en stemning eller oppleve undring. Det er spennende å se hva folk responderer på, jeg får mange overraskelser! Andre dikt er morsomme, eller underholdende og er ikke ment å berøre. De har også sin plass, men til annen bruk.

- Hvordan velger du ut diktene?

- Det er det aller vanskeligste med denne redaktørjobben. Jeg må si nei. Jeg får tilsendt flere dikt hver eneste dag. Jeg må avslå halvparten. Det er ikke plass til alt! I tillegg er det noen forlag som sender meg alle lyrikkbøkene de gir ut. Kvalitet er det viktigste kriteriet. Relevans og aktualitet vektlegges også. Heldigvis har jeg noen poesi-kompetente personer jeg kan spørre om hjelp dersom jeg er i tvil. Poesien sier sjelden noe nytt. Poesien sier de gamle tingene på nye måter, med et nytt perspektiv, en annen måte å bruke språket på, i en form som trenger forbi det vanlige forsvaret og vanetenkningen.

- Hvorfor er det slik, tror du?

- Noe av poesiens styrke er avgrensningen, det korte formatet, det kondenserte, skåret til beinet. Ofte rett på, dønn ærlig. Uventet, overraskende, eller undrende formulert. «Ingen kan skrive mer enn et halvt dikt», sier en svensk poet, «den andre halvparten blir til hos leseren». Det er derfor linjene er så korte. Leseren kan dikte videre, som refleksjon. Du kan ikke si at du ikke har tid. Den tykke Dostojevskij-romanen må jeg utsette til ferien eller pensjonistlivet. Men et dikt har man alltid tid til!

Vedvik er ikke bare leser og redaktør, han har også skrevet dikt selv. Han henter noen av bøkene han har bidratt i og plukker frem en bok. Et av diktene hans ble valgt til forsiden på samlingen Ren poesi del 2. Det er kort, men det er lett å skjønne at redaktøren ville ha det der: «Gjennomskuet og likevel elsket». 


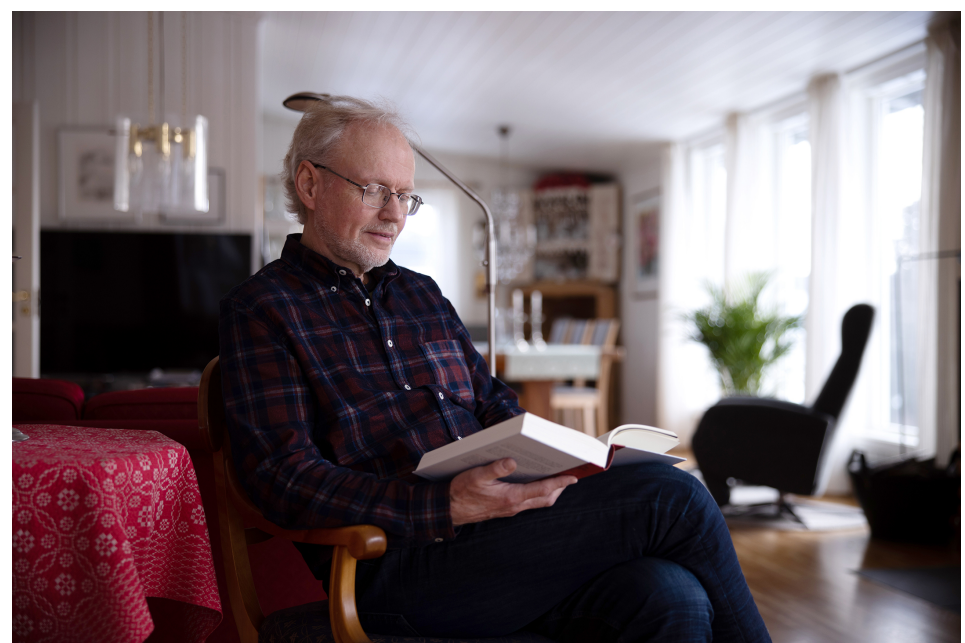

Foto: Frode Mikal Nilssen / Hurdal Foto

\section{Fra Bergen til Hurdal}

- Hvorfor ble du lege?

- Jeg gikk på folkehøyskole her i Hurdal sammen med en student som gikk der for å få ekstrapoeng til medisinstudiet. Der startet det. Det var en helt ny tanke for meg. Jeg hadde allerede fått plass ved NTNU på arkitekturlinjen. Min far var arkitekt. Jeg har ikke angret en dag.

- Mor da?

- Hun jobbet i skobutikk. Min far døde tidlig, bare 55 år gammel, og min mor valgte å ta hjelpepleierutdanning i en alder av 50 år. Så tok hun førerkortet samtidig. Det var imponerende.

- Visste du at det var allmennlege du skulle bli?

- Jeg kunne godt tenke meg å bli kirurg, men de gikk vakter som ikke lignet noe. Min aller første jobb etter turnus var ved legevakten i Bergen. Det er en allmennmedisinsk akuttpoliklinikk og et fantastisk lærested. Siden har jeg vært i allmennpraksis.

Poesien sier de gamle tingene på nye måter

-Så flyttet dere til Hurdal igjen?

- På den tiden var det nesten ingen ledige stillinger for leger i Norge. Da eldstemann ble syv år og skulle begynne på skolen, var vi lei av å flytte rundt. Vi måtte finne et sted hvor man kunne jobbe, bo og leve fast. Det var bare to ledige stillinger da, en i Balestrand og en i Hurdal.

Han liker godt at fastlegens hverdag er variert. Alt kan skje.

- Medisin er tallenes verden med statistikk og referanseverdier. Men tallene kan ikke beskrive alt. Det finnes andre verktøy, bokstaver og språk. Er man fastlege trenger man begge deler. Jeg er veldig glad i jobben min.

- Er det annerledes å være fastlege enn da du begynte?

- Ja, det er det.

- Pasientene er vel de samme? Det er fristende å trekke en parallell til Undsets «men menneskenes hjerter forandres aldeles intet $\mathrm{i}$ alle dager».

- Grunnleggende sett er vi de samme. Men både samfunnet og pasientene har forandret seg mye. Forventningene er større og toleransen for lidelser er mindre. I tillegg er oppgavene til fastleger betydelig utvidet. Det finnes et hav av retningslinjer som ingen rekker å lese fullt og helt. Det er også mindre rom for å gjøre feil og lavere terskel for klager. Jeg har vært «lege for leger» i mange år og har sett hva det gjør med kolleger å få den brune konvolutten fra 
Fylkesmannen. Den er så iskald og saklig. Leger som får en tilsynssak kan sitte oppe om natten og skriver på svaret sitt. De kan sove dårlig og noen kan lure på om de må slutte som leger, eller flytte fra der de bor. Fastleger må svare på alle saker alene, i motsetning til på et sykehus hvor organisasjonen svarer. Hvis din eneste identitet er å være doktor, kan du miste fotfestet. Det går ofte mange måneder før du får svar fra Fylkesmannen. Det er dårlig personalpolitikk, og noen burde ta tak i dette.

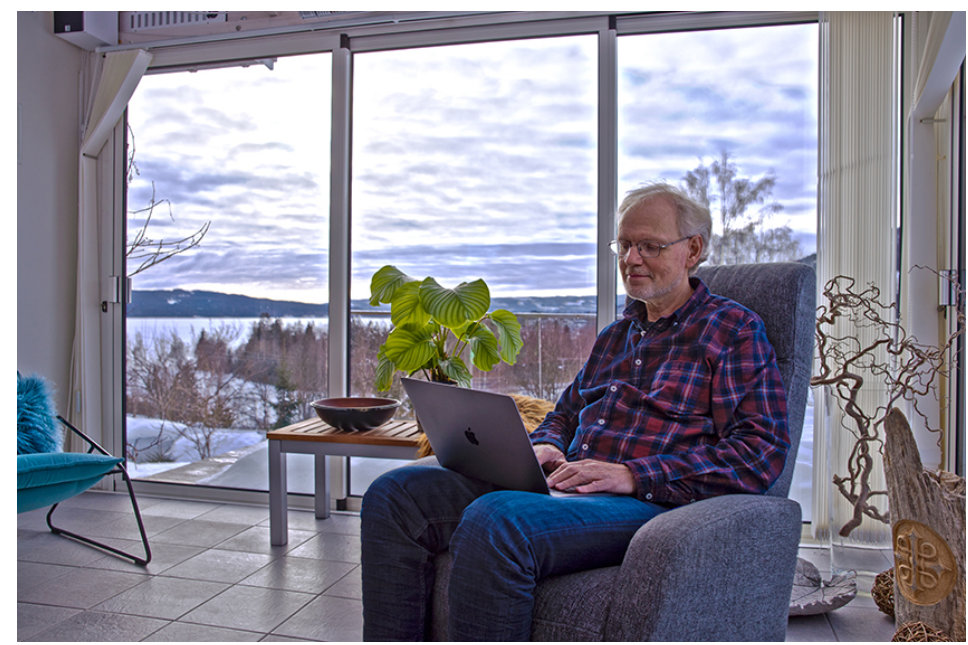

Foto: Frode Mikal Nilssen / Hurdal Foto

- Er du bekymret for fastlegenes fremtid?

- Det har jeg vært lenge. Fastlegeordningen er nede for telling, og myndighetene tar ikke grep. Utredningene ministeren setter i gang er en forhalingsteknikk. Alle vet at en gjennomsnittlig arbeidsuke er 55,6 timer, altså 148 prosent stilling. Pluss legevakt. Nesten ingen i Norge ønsker å jobbe så mye lenger. Når det ikke følger ressurser med oppgavene som ingen ende tar, så vil det ganske sikkert kollapse. Vi trenger mange nye unge leger, men rammevilkårene må bedres om de skal våge å satse. Grunnen til at mange av oss fortsetter å jobbe, er at vi er glade i faget og pasientene. I Sverige har fastlegeordningen spilt falitt, og nå kan vi gå samme vei. I England er primærhelsetjenesten nede for telling. Danmark sliter. Vi må ikke kaste bort det gullet fastlegeordningen har vært. Svenske leger mener at fastlegeordningen i Norge er en av grunnene til at pandemien har gått så bra her.

- Hvorfor fortsetter du?

- Jeg går på jobb hver dag fordi jeg liker å møte pasientene. Det er fortsatt spennende!

Svenske leger mener at fastlegeordningen i Norge er en av grunnene til at pandemien har gått så bra her

- Hva tror du er viktigst for å få flere til å velge fastlegelivet?

- Rammevilkårene må bedres, med kortere pasientlister og mer normal arbeidstid. Dette blir enda viktigere fremover, siden tre av fire medisinstudenter er kvinner. Jeg tror en av hemmelighetene ved å trives i jobben over tid er å ta faget tilbake. Byråkratene vil ha møter og erklæringer, men ingen ble lege for å flytte papirer. Vi ble leger for å hjelpe folk, og det er viktig at vi får drive med kjernevirksomheten. Videre er det viktig at man har flere ben å stå på, enten det er familie, venner eller andre interesser. Det å få lov til å være fastlege er et privilegium. Folk gir et vindu inn til sine liv, og vi får lov til å lytte og av og til hjelpe. Vi har en takknemlig oppgave, og får mye belønning direkte av arbeidet. Det å oppleve takknemlighet er like motiverende som lønn for meg. Det gir jobben mening.

Vi har snakket lenge. Sola har varmet opp vinterhagen og kona har kommet hjem fra en lang gåtur i finværet. Han insisterer på å sende med resten av kanelbollene som niste. Jeg pakker sakene og skal til å gå, men brenner inne med et spørsmål. Typisk for fastleger å få et siste spørsmål mens man holder i dørhåndtaket.

- Det går kanskje ikke an å spørre om du har et yndlingsdikt? 
- Jo, det har jeg! Han svarer uten å nøle: «Romanska båger» av Tomas Tranströmer. Jeg skal sende det til deg.

Publisert: 4. mars 2021. Tidsskr Nor Legeforen. DOI: 10.4045/tidsskr.20.1001

(C) Tidsskrift for Den norske legeforening 2020. Lastet ned fra tidsskriftet.no 